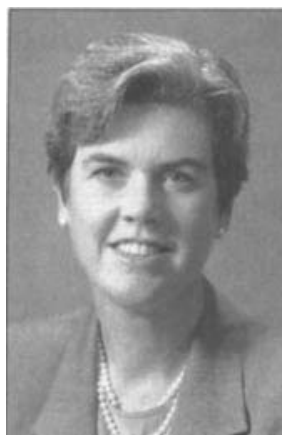

\title{
UC addresses challenges to the California family
}

\author{
BARBARA SCHNEEMAN \\ Dean, College of Agricultural and Environmental Sciences \\ UC Davis
}

W e are all members of a family, and our knowledge of family structure and function is strongly influenced by personal experience. In fact, our families are so basic and familiar, guiding our earliest initiation into social life, that we frequently overlook their fundamental contribution to the viability of our economy and society.

Diverse groups use similar words and phrases to characterize families; however, we do not have a common scientific base or understanding of that language. This dilemma is perhaps best illustrated by the public debates in which the term 'family values' is used to convey a political agenda, with the agenda varying by the group using the term. By recognizing the United Nations' International Year of the Family, we can raise the level of discussion about the function of families in society and recognize the knowledge needed to support this vital unit. We also have the opportunity to focus on California's unique human resources - their diversity and their multiple modes of problem solving. These efforts will only be successful if the Year of the Family is seen as the beginning of a constructive dialogue, not simply a commemorative event.

When the land grant university system was established in 1862, the majority of Americans were involved in family farming. Research and extension programs focused on promoting the success of this system. Many of the University of California's highly effective programs in food, nutrition, clothing, human development, design and financial management developed from this heritage. Today's urbanized families still have a profound connection to agriculture and the land-grant university. It is families who support education, consume agricultural products, utilize land and environmental resources, provide labor, and teach values - the values that guide society's use of natural resources. For instance, consumers can and do influence agricultural production through their market decisions. Their concerns about food safety have had a profound impact on farming systems.

Yet the impact of our institutions and policies on families is often overlooked. We routinely generate environmental and economic impact reports, but have no comparable process for assessing family impacts. Ultimately, the myriad decisions made by families determine environmental or economic impacts. It is families who decide to move from one area of the country to another, to keep land in production or sell it for development, to buy or rent housing, to visit the national parks. Families decide whether to migrate with seasonal crop pro- duction, how to provide for their children's health and education, whether both parents should work outside the home, and which foods and clothes to buy. Family decisions may or may not promote functional communities that protect the health and welfare of members. If society gave greater consideration to the family impact of institutions and policies, the community as a whole would benefit by allowing each of us to fulfill our family roles.

The contributors to this special issue provide insight into how programs that relate to families are integrated into UC's Division of Agriculture and Natural Resources. For many years, the disciplines of production agriculture and those concerned with agricultural consumption were viewed as discrete entities. Today we recognize they are parts of a continuum. Shelter, food and clothing are fundamental needs of individuals and families. Child care, health promotion and youth development are critical components affecting the quality of life of all individuals and families. The sustainability of both UC and the state's agricultural enterprise depends upon our ability to respond to the needs and interests of individuals in the context of family life.

Furthermore, if we agree that families are the fundamental units through which society teaches values, and provides food, shelter, clothing and education, we must consider how all families can gain access to the basic necessities of an active and healthy life. The articles in this special issue raise questions about how well our society is performing this role, and offer hope that strong research and extension efforts can provide at least partial answers to the myriad challenges facing California families.

Families and communities are our most valuable resources. It is my hope that this special issue of California Agriculture will mark the beginning of an essential public dialogue. UC can and should play a critical role in the discovery of knowledge about the social and cultural value of families and the integration and extension of this science to serve society.

Publication of this special, seventh issue of California Agriculture (in addition to the normal six printed this year) was made possible by funding from the Office of the Vice President, Division of Agriculture and Natural Resources. Guest editors for the issue were UC faculty members Doris Calloway, Larry Harper, Susan Laughlin and Jeanette Sutherlin. Valerie Sullivan was the free-lance editor for this special issue. 